\title{
Conceptual Analysis and Fieldwork in Macroeconometric Methodology: Modeling Unemployment, Inflation and Production
}

\author{
Karim Errouaki \\ Foundation for the Culture of Peace, Autonomous University of Madrid, Madrid, Spain \\ Email: errouaki@yahoo.fr
}

Received 20 June 2014; revised 2 August 2014; accepted 21 August 2014

Copyright @ 2014 by author and Scientific Research Publishing Inc.

This work is licensed under the Creative Commons Attribution International License (CC BY). http://creativecommons.org/licenses/by/4.0/

(c) (i) Open Access

\section{Abstract}

The recent failure of commonly accepted, inductive, econometric models to provide insights into real, macroeconomic phenomenon during economic crises has provoked a debate concerning contemporary econometric methodology. Based on the foundations laid by Haavelmo, and Hollis and Nell, an assessment of Edward J. Nell's (1998) "unifying methodological framework" (UMF) is offered. Nell's UMF places socioeconomic institutions and interdependencies, and technological realities as basis of analysis. Using "conceptual analysis" and "fieldwork" Nell presents an alternative to generally accepted, mainstream, econometric methodology. The purpose of this paper is to look at some examples of the way, and this can help develop useful theory and improve macroeconometric model building. Applying Nell's UMF to unemployment, inflation, and production reveals a methodological advance that promises more realistic insights into macroeconomic phenomena than is offered by contemporary, mainstream, econometric models.

\section{Keywords}

Conceptual Analysis, Fieldwork, Identification, Inflation, Macroeconometric Model Building, Methodological Institutionalism, Production Function, Specification, Unemployment

\section{Introduction}

During the 1950s and 1960s leading econometricians developed large-scale and detailed models of the economies of the USA and the UK. These models worked well enough that they became accepted as aids in policy-making, in particular, as guides to understanding the likely results of policy interventions. But in the 1970s, when the world was experiencing unprecedented shocks, the models broke down (e.g. Klein, 1985) [1]. They 
failed to predict the onset of domestic and foreign exchange crises, nor did they accurately portray the effects of the oil shocks; they failed to forecast the consequences of policy responses. It appeared as though the commonly accepted methods - using inductive approaches — had failed (e.g. Nell and Errouaki, 2013; Vercelli, 1991) [2] [3].

In more contemporary terms, Spanos (2012, p. 3) has argued that the economists participating in the debate during the more recent global financial crises that began in 2008 were suggesting different economic policies on how to deal with the dangerous and eminent collapse of the world's monetary system and the looming global recession that invariably invoked causal knowledge between key policy variables [4]. Indeed, the recent financial crisis has sparked a debate about the limitations of the inherently stable micro-founded models that are currently dominating modern macroeconometric research and that are used as analytical tools by many central banks. A renewed interest in the examination of the foundations of macroeconometric methodology of model building is evident in the context of the debate around the financial crisis (e.g., Akerlof and Shiller, 2009; Fair, 2012) [5] [6].

The recent financial crisis has also led to a debate about the limitations of current macroeconomic models. Some will claim that it is time to reconsider our perception of 'macroeconomics and reality' (Nell and Semmler, 2009; Stiglitz, 2011) [7] [8]. What lies behind such a confusing state of affairs? Were the theories wrong? Were the methods inadequate? What should econometricians have done differently?

To address these questions, economists would make confident assertions, proposing explanations and predictions that were often at odds with equally confident assertions from other economists. The most concerning result of these debates is that most economists seem unconcerned by the fact that their predictions are rarely borne out by the real economy.

A great deal of work in macroeconomics and macroeconometrics has gone down an unpromising road (Malinvaud, 1988, 1998; Fair, 2004) [9]-[11]. Haavelmo and Klein among others have always insisted on a good theoretical basis for equation specification, a basis that has to be in close correspondence with reality. Haavelmo (1997, p. 15) argued that econometrics can be useful, but he insisted that the possibility of extracting information from observations of the world we live in depends on good economic theory [12]. Klein (1987, p. 416) was in full agreement with Haavelmo regarding the importance of theoretical basis for equation specification [13]. However, as Hendry (2004, pp. 759-760) [14] puts it, "that still leaves open the crucial question as to which economic theory".

Nell $(1998,2004)$ proposed a new vision that puts methodological institutionalism in place of methodological individualism [15] [16]. Hollis and Nell (1975) exposed and explained the methodological deficiencies of modern econometrics before they had become widely realized [17]. Moreover, Hollis and Nell's framework, and Nell [15] [16], suggested a way of fixing the problems. Nell and Errouaki (2013) have argued that neo-Classical economic theory provided the ontological basis (the rational individual) and the corresponding individualistic methodology of the modern econometrics that has come to replace the Haavelmo (1944)-Cowles Project [18]. The result is that neo-Classical-based econometrics fails to develop any insight into deep structures-it interprets whatever it sees as individuals choosing with some degree of (perhaps bounded) rationality. It simply relates observables to one another, putting choices and actions together into equilibrium patterns.

Nell's unifying methodological framework ${ }^{1}$ offers a new approach, an ontological turn that ensures that socioeconomic reality, understood through fieldwork, will be what defines the terms of the model, and not the other way around. The main thesis of this paper is that macroeconometric methodology of model building must be informed by theory, but the theory cannot be abstract and axiomatic. On the contrary, it must rest on conceptual analysis and fieldwork.

The purpose of this paper is to look at some examples of the way; this can help develop useful theory and improve macroeconometric model building. The focus will be on unemployment and inflation, two highly charged, politically sensitive issues, but ones where nearly everyone has some relevant, direct experience. Then the modeling of production functions will be discussed. It is hoped that this discussion has significant implications for the long standing debate over the scientific foundations of structural econometrics and macroeconomic policy based on economic realities rather than theoretical presumptions.

\section{Nell's Unifying Methodological Framework}

Nell's UMF proposes a self-replacing system-a socioeconomic system-that acts as a data-generating me-

${ }^{1}$ Nell's unifying methodological framework is a synthesis between [17] (early Nell) and [15] [16] (late Nell), and inspired by a novel re-reading of [18], refocused on econometrics. In fact, there is an intimate interrelation between [17] and [15] [16] which precludes separate consideration. UMF is a blend (albeit natural) of early Nell and late Nell combined with a pinch of [2]. 
chanism². On this basis, Nell $(1998,2004)$ proposes “methodological institutionalism” as an alternative to methodological individualism, contending that there are law-like relations to be discovered in the economy, though they are not the same as the law-like relations in the physical sciences [15] [16]. The Keynesian concept of "uncertainty" should be seriously considered; there are some variables and some relationships that exist and are important, but which are inherently liable to shift unpredictably. We can identify and estimate them temporarily — and unreliably — but we cannot capture them once and for all. Their nature reflects our abilities to innovate and to change our minds, and this cannot be fully accounted for in a model.

Nell's UMF reflects Haavelmo's (1944, 1958, 1997) econometric thinking and it is superior to that advocated by pragmatism, which cannot give a coherent account of theoretical concepts, especially in relation to empirical work, and by contrast leads, to use Nell's expression, to "armchair empirical work" [12] [18] [19].

However, fieldwork may be directed toward economic structure or towards behaviour. Indeed, the idea of fieldwork is discussed implicitly and eloquently by Haavelmo (1958, pp. 355-357) in his Presidential address to the Econometric Society [19]:

It is probably fair to say that the interest of econometricians in the field of pure economic theory has been more in the direction of the "repair work" that I spoke of, rather than an interest in the fundamental economic ideas themselves.

The idea of bringing econometric thinking into theory at an early stage is not merely that of being able to throw out theoretical schemes which are unrealistic in a narrow sense. We must learn to think of facts to be

explained in a broader sense, as things that could be facts even if they are not at present.

Klein (1987) and Johnston (1984) support fieldwork and they want it integrated with other sources of information - that is, they want it subjected to conceptual analysis [13] [21]. Johnston (1984, p. 500) in a study of cost-output relationships in coal mining, "felt it useful to don a safety helmet and work his way through the narrow and twisting seams of a Lancashire coal field in order to see at firsthand the nature of the production process before sitting down to pursue the statistics at the regional headquarters of the National Coal Board" [21]. Johnston used fieldwork to understand the mining sector. He studied it in its own terms, and then translating those terms into the observer's language.

Nell (1998) argues that economic theory should try to explain the causal mechanisms that generate observed economic phenomenon. The goal of Keynes's General Theory was to provide a historically founded and institutionally specific macroeconomic explanation for the phenomenon of unemployment in the interwar period to devise appropriate policy solutions. Keynes (1936, p. 276) wrote: “A scientific theory cannot require the facts to conform to its own assumptions” [22]. Keynes (1973, CW XIV, pp. 296-297) explicitly rejects the deductive approach in which the basic assumptions are axioms that are true a priori [23].

Like Keynes, Nell argues that capitalism is constantly changing so that the economic theorist has to keep abreast of new historical developments because these might present a break with the past, thus making part of the prevailing theoretical wisdom obsolete. Nell's approach to macroeconomic model building is in fact an attempt to follow Keynes's lead in creating such a historical macroeconomics.

Nell proposes that conceptual analysis, fieldwork, and model-building, interact and constitute the backbone of his UMF. Each element can help to extend and develop the others. No single criterion governs all. Each draws on precepts and practical maxims peculiar to itself, but each provides assistance to the others, and in some measure each is necessary to the others.

\subsection{Conceptual Analysis}

Nell (1998) argued that conceptual analysis can provide guidance in adapting these general points to particular cases through empirical fieldwork (not library studies) [15]. As a consequence, conceptual analysis of fieldwork can then put together the real patterns of behaviour and motivation, in the context of the available and actually operating technology-ways of working, making and doing things. Such conceptual analysis may be concerned with deconstruction, a literary analysis taking apart the reported picture, discovering concealed meanings and hidden agendas, both on the part of observers and the observed. The resulting view of the economy gives rise to an account of value, competition, and markets that differs from the mainstream. It supports the view that history

\footnotetext{
${ }^{2}$ Granger (2004, p. 97) [20] argued that "the concept of a data generating mechanism is only an abstract concept used by econometric theorists as the ultimate aim of an asymptotic analysis. It is not considered an achievable structure or objective”.
} 
cannot be properly studied by equilibrium methods, and that economic analysis is likely to be different in different historical eras.

The isolated individual cannot be the basis for economic analysis. More generally, human life is built around social relations; economics, in particular, depends on property, for exchange is the exchange of ownership rights. Rights, in turn, depend on contracts-i.e., promises that give rise to obligations. But that depends on authority; contracts must be enforced, which requires judgements and settlements of disputes. Hence there must be rules and institutions. Agents in turn interact with the world; they are able to affect and alter material objects in various ways - which is production. How they do this is the province of technology. Thus the economic activity of agents rests on two foundations: their relations with each other-institution and their relations with the material world—and in particular, technology.

The activities of investing and producing require engineering skills, based on technology, which sums up the various ways agents can affect the material world and bend it to their purposes. In doing so, agents, being themselves material objects, must also alter themselves and their relationships. Technology is not simply a set of ways agents can affect the world; to affect the world agents must also alter themselves and their institutions.

Technology ultimately rests on principles elaborated by physics and chemistry, just as institutions reflect the limits and possibilities implied by biology. Ultimately is important to recognize that neither physics nor biology determine any economic relationships. But the portrayal of economic relationships must be consistent with the basic principles of each. Conceptual truths in economics, then, trace the general forms of the relationships holding between economic agents, on the one hand, that is economic institutions such as firms and households, and between agents and the material world-i.e., technology, bearing in mind that agents themselves are part of the material world.

\subsection{Fieldwork Approach}

Fieldwork is scholarly work that requires first-hand observation, recording or documenting what one sees and hears in a particular setting. It has long been regarded as the mainstay in anthropological research. The principle here is that to understand, and sometimes even to discover the truth, it is necessary to investigate the world, and, perhaps, to investigate investigating.

The purpose here is to move from the very general level to the study of a particular society and economy. This leap cannot be made by collecting some statistics and trying to fill in the general categories developed by conceptual analysis. First, the general categories have to be adapted to the particular case. This has been done by the people of the particular society themselves. We, the observers, have to discover how this adaptation has taken place, in the history and development of the society. This requires what anthropologists call fieldwork.

The first generation of anthropologists ${ }^{3}$, studying mostly people under colonial rule, had tended to rely on locally based missionaries and colonial administrators to collect ethnographic information, often guided by questionnaires that were issued by theorists from "back home". In the late, nineteenth-century, important ethnographic expeditions were organized, often by museums. As reports came in, academics would set out the findings in comparative frameworks to illustrate the course of evolutionary development or to trace local historical relationships. Contemporary ethnography is based almost entirely on fieldwork and requires the complete immersion of the anthropologist in the culture and everyday life of the people who are the subject of study. A relevant contemporary example of economic fieldwork is Ho's (2009) on Wall Street [25] ${ }^{4}$.

A fieldworker spends a great deal of time observing people. As Thomas (2004, p. 150) has reminded us, social scientists are privileged in being able to ask direct questions of the objects they study. Physicists are not able to interview their atoms; if they could, would they be able to remove some of Heisenberg's uncertainty? [26].

Mintzberg (1973) played a crucial role in the popularization of fieldwork in management [27]. This pioneering work established his reputation worldwide as a major figure in the field of management and ethnography of

\footnotetext{
${ }^{3}$ Malinowski (1922) is credited as being the most important figure in the development of the modern fieldwork tradition, through his study of the Trobriand Islanders of New Guinea [24].

${ }^{4}$ Ho looked into the everyday experiences and ideologies of Wall Street investment bankers, the everyday world of investment banking before the crisis. She describes how a financially dominant but highly unstable market system is understood, justified and produced through the restructuring of corporations and the larger economy. She delves into the roots of excessive risk-taking. She worked at an investment bank and shows that bankers' approaches to financial markets and corporate America are inseparable from the structures and strategies of their workplaces; their mission is the creation of shareholder value, but their practices and assumptions often produce crises instead [25].
} 
organizations. Mintzberg adopted a method that had hardly ever been used in management research: direct and structured observation (i.e., fieldwork) ${ }^{5}$. This method requires the researcher to follow the steps of each of the general managers no matter what activity they are doing. He must carefully note the slightest action, recording the amounts of time spent on each and entering all the data on a grid, which is later to be used to do breakdowns and calculations, make comparisons, and so forth. With the arrival of Mintzberg, the question was no longer what must or should be done, but what a manager actually does during the day. Mintzberg discoveries and deductions appeared to be a veritable revolution.

Fieldwork means finding out what people actually do, how they actually think and behave, and what they mean when they say something. Fieldwork has not been widely discussed or widely employed in economics, but it has been there right from the beginning. Adam Smith visited a pin factory, and observed it closely. This led him to explain how the division of labour worked. In general, however, economists have not done much fieldwork ${ }^{6}$.

Without fieldwork, our numbers and therefore our statistics will give us a distorted picture of the world. Without fieldwork, we cannot know the operating rules in our economic institutions, or the true motivations of agents. A different but even more extreme case is provided by's Lucas's (in) famous claim that "involuntary unemployment is not a factor phenomenon which it is the task of theorists to explain. It is a theoretical construct which Keynes introduced in the hope that it would be helpful in discovering a correct explanation for a genuine phenomenon: large-scale fluctuations in measured, total employment” (Lucas, 1987, p. 354) [30] ${ }^{7}$. Even minimal fieldwork will establish that "involuntary unemployment", in the normal sense of the term, is a fact, and, moreover, one in need of explanation. Further (historical) fieldwork will show that the character of employment in leading industrial countries changed from before 1914 to after 1945. The legal, regulatory and institutional arrangements changed.

If economists were to undertake fieldwork it could take two basic forms. One can give us a carefully drawn picture of institutions and practices that it apply to all activities of a certain kind in a particular society or social setting, specifically focused on that society or setting. Although institutions and practices are intangible, such a picture will be objective, a matter of fact, independent of the state of mind of the particular agents reported on. Another form can come from better understanding, through observation, the state of mind of economic agentstheir true motivations, their beliefs, state of knowledge, expectations, their preferences and values. The results of this research will also be matters of fact, but they will be records of the subjective states of the agents reported on - their feelings, attitudes, beliefs, preferences and values. Fieldwork is reporting, but it is at the same time an exceptionally sophisticated reporting because it requires the observer to penetrate the disguises of key roles in society and the economy. This requires careful judgement, since the mask will usually display a partial truth.

\section{Examples of Fieldwork and Conceptual Analysis}

In economics, conceptual analysis of fieldwork can pull together the real patterns of behaviour and motivation, in the context of the available and actually operating technology, ways of working, making and doing things. Such conceptual analysis may be concerned with "deconstruction”, a literary analysis taking apart the reported picture, discovering concealed meanings and hidden agendas, both on the part of the observers and the observed. An important part of this will be uncovering the presuppositions of the concepts and activities reported by fieldwork. Or the programme of economics may accept the picture, and set out to construct models that will show how the system works in various ways, including how it may fail to work and break down.

We cannot expect a theory to leap out of the statistics on its own. We have to interact with the world to understand it, and we have to bring to bear all the methods of investigating we can (e.g., Haavelmo, 1958) [19]. This requires looking at the economy with open eyes, gathering interview data, carrying out practical activities (shopping, banking, applying for jobs, going to work) and then thinking about what we have found. When we use statistics we have to reflect on exactly what they mean-what do these numbers represent, in reality?

If adequate fieldwork has not been done, no one will know what the numbers mean. Fieldwork will give us

\footnotetext{
${ }^{5}$ The Economist magazine (16 January 2009) pointed out that "Mintzberg found that managers were not the robotic paragons of efficiency that they were usually made out to be. The pressures of his job drive the manager to be superficial in his actions - to overload himself with work, encourage interruption, respond quickly to every stimulus, seek the tangible and avoid the abstract, make decisions in small increments, and do everything abruptly".

${ }^{6}$ The work of Blinder (1998) [28] and Bewley (1999) [29] are other good illustrations of the relevance of fieldwork in economics that Nell has advocated since the publication of his [15] book. Surveys of consumer confidence (survey research centre, Oxford surveys, Conference Board, INSEE surveys) reflect fieldwork, but most so-called empirical work today is based on number-crunching [15].

${ }^{7}$ See also the commentary of Rosenberg (1992, pp. 77-78) [31].
} 
the concepts, but then the concepts have to be fitted into a realistic structure- - a structure that must, however, be more precise, more realistic and, in many respects, more complex than any heretofore available. In formulating its abstract quantitative notions and concepts, theory must be inspired and guided by the techniques of observation in the field. Indeed, Haavelmo (1958, 1997), Johnston (1984), Klein (1987), Nell $(1998,2004)$ and Nell and Errouaki (2013) have warned us that "armchair empiricism" will not do the job [1] [2] [12] [15] [16] [19] [21].

It is worth considering three examples of the way this approach to economic investigations can help develop useful theory and improve econometric model building. The first two examples are unemployment and inflation - two highly charged, politically sensitive issues that nearly everyone has some relevant direct experience with. The third example will consider the nature of production.

\subsection{Unemployment and Inflation: Some Implications of Fieldwork}

Fieldwork is serious investigative work; it is a kind of detective work to find out what people are really thinking and really doing. Fieldwork calls for looking at budgets and accounts, checking statistics, studying court records, government documents, contracts, administrative rules, normal procedures, and what people believe to be the norms and traditions of society. It requires talking to people to find out how they understand and interpret the everyday activities of their lives - what do their actions mean, what does the collected data mean? This must be done with a scientific attitude, not with the aim of reaching a pre-ordained result. Every effort has to be made to control bias and lay bare unconscious presuppositions-points better understood by anthropologists than economists. The result should offer a rough picture of how things work.

Does unemployment reflect aggregate demand, or does Say's Law hold? Is there "involuntary unemployment?” The Keynesian idea is that unemployment exists because firms will not hire labour that is available and willing to work at an acceptable wage, because the goods and services they would produce could not be sold in current markets. There is a "shortage of demand" in relation to available capacity and labour, and because of it workers are unemployed involuntarily. However, given investment, government spending, and interest rates, consumption may be such that this shortage of demand will be associated with a steady-state, equilibrium-i.e., there are no forces operating to correct the shortage of demand. Interest rates may be under no pressure to fall, investment will not rise in the face of underutilized capacity and, in the absence of active policy, government spending will be steady. With unemployment and hard times, households are likely to cut back, so, if anything, consumption will tend to drift down.

Mainstream economics, however, argues that there cannot be any such thing as "involuntary unemployment" at equilibrium. It is a consequence of the "theorem of the alternative" that if the product market is in equilibrium, then, if a factor has a positive price, it must be fully utilized. So, in equilibrium there cannot be unemployed labour.

The mathematical point is correct, of course; but it certainly does not prove that there is no involuntary unemployment. It could be taken to mean, for example, that markets are generally or commonly in disequilibrium, but lack strong corrective forces. What appears to be unemployment is due to extended job search, or to unanticipated fluctuations in productivity. Many economists subscribe to such views without realizing the damaging implications. The mainstream theoretical concept of equilibrium rests on too many far-fetched assumptions to be a reflection of the observable economy.

The mathematical point could be taken to suggest a more radical suggestion that values are not determined by scarcity; that is to say, that prices do not result from the equilibrating interaction of relationships that depend on maximizing subject to constraints. This may sound shocking to some (but it has the support of Maurice Allais (1997, p. 7) [32]), yet the commitment to scarcity thinking and optimizing sustains the widespread belief among economists that most unemployment is voluntary; this idea has never been held widely among any other groups. Indeed, to deny the reality of unemployment (and its costs to families) may be considered a sign of ignorance of how the world actually works; it certainly suggests that fieldwork has not been done.

Now consider the causes and nature of inflation. Many claim that inflation is caused by excess demand driving up prices and/or wages. Others consider inflation to be a collapse in the value of money resulting from an excessive supply of money. Finally, observers of households and industry argue that inflation-persistently rising prices-is due to rising costs of business and/or rising costs of living. Again, the idea that inflation is due to excessive issuance of money is probably more common among economists than in the general public. Most people know that costs and demand have something to do with inflation. 
These views - that there is no involuntary unemployment, that the driving force behind inflation is chiefly issuing too much money-cannot be sustained in the face of serious fieldwork. It is true that under the conditions of the craft economy (i.e., an economy dominated by family firms and family farms, not industrial mass production) both views were reasonable - not exactly Say's Law, but there was a weakly stabilizing price mechanism (flexible prices and inflexible employment), where excessive issues of money, lowering interest and stimulating spending, might well drive up prices in the short run. Today, in parts of the developing world, the conditions of the craft economy can still be found. So there is some justification for the fact that these ideas are still widespread. Many economists doubt that there is a single principal explanation for unemployment or inflation; instead, we should expect multiple causes, so Say's Law and monetarist explanations could play a role. On this view, the important job would be to assess the respective contributions of these and other possibilities through fieldwork. However, fieldwork would very likely rule out the generally held positions when it comes to advanced, industrial, mass production economies.

\subsubsection{Fieldwork and Explaining Unemployment}

Keynesians argue that fluctuations in aggregate demand are endemic (and do not necessarily indicate a disequilibrium), and that, in the modern world, business adapts to these fluctuations by adjusting employment. In the nineteenth century, fluctuations in demand led chiefly to changes in prices, followed only later by smaller changes in employment (Marshall and Marshall, 1879) [33]. Employment is chiefly determined by what happens in the product market. Traditional theory asserts Say's Law, that once the supply side of the economy is properly specified, it will automatically generate the appropriate level of demand. Fluctuations in final demand are not the cause of variations in employment. On the contrary, according to the "real business cycle" approach, variations in employment reflect short-term variations in productivity, usually not matched by appropriate wage adjustment. In this view, of course, employment is determined chiefly in the labour market, rather than responding to the demand for goods and services.

To begin, consider the question of whether some, or most, unemployment is "voluntary" or "involuntary", where the latter means that the worker would be willing to take a job even at a level of pay below the current market rate. This calls for interviews with the unemployed themselves, collecting not only statements, but their stories, then interviewing their previous employers, employment agencies and prospective employers, to discover why employers have downsized or laid off workers and what would make them willing to start hiring again. The results, of course, would show that many unemployed workers are willing to work at or below prevailing wages, have spent time and effort looking for a job, and can't find one because business hiring is slow. We know this from Keynesian macroeconomics, obviously; the point is that it can be confirmed by a completely independent body of evidence gathered by fieldwork. Furthermore, most of us know it as part of "common knowledge"-we know people who were laid off and who had a terrible time finding another job. We know businesses that have had to lay off workers, an action both sides would have preferred to avoid.

In the same way, we know from ordinary macroeconomics that declining sales, due to declining aggregate demand, causes businesses to lay off workers. Demand does not always stay at the level of full employment; it fluctuates and this causes changes in employment, layoffs in bad times, extra hiring in booms. Again, interviews with managers, checking personnel records, and interviews with union officials will confirm this. Moreover, most of us from personal experience know of a shop or business that has had to shut down or lay off employees because of sagging sales. The alternative explanation offered by "real business cycle" theorists, that employment and output levels fluctuate because of technology and productivity "shocks", will not fit with what personnel managers say, nor will it accord with what the engineers say. Layoffs may increase but the actual technology has not changed.

\subsubsection{Fieldwork and Explaining Inflation}

Mainstream economics has not done a good job with inflation. In general, it has done a poor job of integrating the monetary side of the economy with the real side. The problems of the large econometric models in the 1970s were less in estimating than in specifying relationships and model structure, particularly the relationships between the real and the financial aspects of the economy-very closely related to the reliable/volatile distinction. This was particularly true of production; fixed coefficient models held up well, but neo-Classical marginal productivity models turned out to be deeply flawed - they purported to estimate production, but actually captured cost identities (see below). Yet the estimations of many particular relationships often proved sound; parts of the 
models held up throughout. These were the reliable functions-household consumption spending on various categories of goods and services, labour productivity in the different sectors, import propensities, multiplier relationships-all these generally came through well (Hendry, 1995, p. 100) [34]. In these functions the "targets" are well defined, we know what the process is aiming at or trying to achieve-so there are good reasons to expect certain mean values. And the forces or pressures that bring about "misses" are also well understood; we know what gets in the way of achieving the targets, or causes deviations.

But monetary and financial relationships did not fare so well. Investment and interest rates proved troublesome, and the stock market elusive; but inflation was the "killer". The big models tended to get it seriously wrong. For the models were built around the Phillips Curve, or the NAIRU (non-accelerating inflation rate of unemployment), which made it difficult to accommodate the simultaneous development of unemployment and inflation-stagflation.

This should not have been such a surprise. The Phillips Curve is not robust econometrically; it does not test well and indeed, Wulwick (2001) has argued in detail that the original version would not pass elementary methodological scrutiny today [35]. Many different versions have been estimated, and the results are not generally compatible. Neither the reasons for target levels nor the forces causing deviations have been clearly specified and well-defined.

The original version rested on the view that all inflation is demand-driven; lower unemployment reflects a spending boom that puts greater pressure on markets, so prices/wages tend to be driven up. The cost of lower unemployment is higher prices. Early Keynesian thinking considered this reasonable, even though the evidence was not very strong. Moreover, it was not clear that this established a relationship between changes in demand (unemployment) and inflation. The change in demand and employment might be permanent, but the corresponding change in prices might be once-for-all, the consequence of adjusting to a higher level of capacity utilization.

Critics like Friedman and Phelps shifted from Keynesian to pre-Keynesian thinking, and argued that causality ran from inflation to unemployment, through the labour market, and further that the trade-off was only valid for the short run. Instead of arguing that lower unemployment means higher demand pressure, bringing about inflation, the critics contended that higher inflation (caused by increases in the money supply) leads to temporarily lower real wages, leading business to hire more labour. But money illusion is only temporary; labour will soon realize that real wages have been lowered and will demand higher money wages, perpetuating the inflation, but leading unemployment to rise once again to its natural level. So reducing unemployment markedly by policy must lead to a permanent rise in inflation; but the unemployment rate would not remain permanently lower. It would rise again, to a "natural" rate. In the same way, if it were too high, it would eventually fall to the "natural" rate. At this unemployment rate, however, there would be no tendency for the inflation rate to either increase or decrease. This rate of unemployment was christened the "NAIRU".

This entire line of argument is defective: it has two flaws, each of them fatal. First, it assumes that changes in the money supply, controlled by the Federal Reserve (in the USA), will move nominal aggregate demand more or less in the same proportion. Careful study of how the Fed actually works shows that the Fed does not have that degree of control over money (Moore, 1988; Nell and Forstater, 2003; Nell and Bell, 2003; Wray, 2003) [36]-[39]; and money does not govern nominal demand (even the correlations are unreliable, and critics contend that Monetarist causality has never been adequately explained (Robinson, 1980; Nell, 1998) [15] [40]. Second, it is based on the neo-Classical picture of the labour market. Fieldwork should tell us that over most of a modern economy "marginal products" in the required sense cannot be identified-i.e., outputs cannot be identified and attributed in the required manner. Moreover, marginal costs are constant or falling; employment is adjusted to sales or to inventories. The neo-Classical negatively-sloped demand curve for labour simply does not exist. Conceptual analysis then says that the model of the economy must show employment being determined by the level of demand in the product market in conjunction with the output function. These relationships are measureable. The neo-Classical labour market is conceptually defective.

Instead of a Phillips curve or a NAIRU consider a wage-price spiral (Nell, 1998) [15]. There are two relationships here (Flaschel et al., 2008, ch 3) [41]. The first shows the ability of workers, unions and households to push up wages in response to a rise in the cost of living. If the cost of living goes up by $\mathrm{x} \%$ in period 0 , the wage will be driven up by $a x \%$ in period 1 , where $a>$ or $=0$.

$$
(\mathrm{d} w / w)_{1}=a(\mathrm{~d} \pi / \pi)_{0}
$$


where $w$ is the money wage and $\pi$ is the level of prices.

The second equation shows the response of business to a rise in labour costs. If wages rise by $\mathrm{x} \%$ in period 0 , then business will impose a price increase of $b x \%$ in period 1 .

$$
(\mathrm{d} \pi / \pi)_{1}=b(\mathrm{~d} w / w)_{0}
$$

So

$$
(\mathrm{d} w / w)_{1}=a b(\mathrm{~d} w / w)_{-1}
$$

And

$$
(\mathrm{d} \pi / \pi)_{1}=a b(\mathrm{~d} \pi / \pi)_{-1}
$$

(Example, $a=2 / 3, b=3 / 2$. Steady inflation, but every period the real wage falls.)

When $a b=1$, the system exhibits steady inflation, when $a b<1$, inflation converges, and with $a b>1$ inflation is explosive. Each of these relationships is solidly grounded in institutional practice. Businesses have to defend their profits, and households their standard of living; in each case an uncompensated rise in costs will create difficulties in meeting obligations. Each therefore will seek to pass along the rise in costs. But their potential success in doing so, indicated by coefficients $a$ and $b$, cannot be assumed a priori, but must be examined case by case.

The effects of this can be seen by looking at the accounting identity,

$$
Y=(w / \pi) N+r K
$$

When differentiated this gives us

$$
\mathrm{d} r=w N / K \pi[\mathrm{d} \pi / \pi-\mathrm{d} w / w]
$$

The rate of profit increases or decreases according to whether price inflation is greater or less than money wage inflation. The impact of inflation is on distribution, as in Kaldor's approach, and can therefore be expected to generate feedback effects on aggregate demand.

Notice that we are here modelling both money wages and prices on the basis of normal costs, costs of living for households, and costs of producing for firms. Each is assumed to try to pass along any increases in such costs. The equations shown here simply model the basic idea; by contrast, fieldwork suggests that the equations to actually estimate the inflationary process should contain additional terms for technological change, for feedback effects from changes in distribution and from changes in inflationary expectations (Rose effects and Mundell effects).

A more problematical issue concerns whether the two equations could also be written as reflecting demand pressures, rather than costs. The wage equation would then show the money wage rising with demand pressures as these caused deviations from the normal level of unemployment (NAIRU), and the price equation would show prices rising with the deviation from the normal level of capacity utilization (Flaschel, et al., 2008, ch 3, esp. 3.2) [41]. But I think the wage-price spiral is largely a cost-driven spiral; the chief effect of demand on inflation comes through driving up the demand sensitive prices of primary products. When this does not happen, even very strong demand pressures do not generate much inflation, vide the late 1990s in the USA. (Of course, this is an empirical identification problem.)

In contrast to either version of the wage-price spiral, the monetarist story rests on an assumed "demand for labour" curve, derived from an assumed production function with diminishing marginal products. These concepts have no grounding in contracts, and both appear to be inconsistent with mass production technology. The supposed reaction of business to inflation-hiring more workers-rests on this labour demand curve; we have argued that no such curve exists. Furthermore, the decisions to hire, offer labor, and produce are typically made on the basis of assumed "mistakes" about the level of the real wage by one or another party. In the short run these mistakes supposedly generate a Phillips curve, but the system eventually returns to its natural position, where the long-term real wage is given by the marginal product at the natural rate of unemployment. In our view, neither the Phillips curve nor the "natural rate" exist.

What are the benefits of our suggested approach (bearing in mind that it's not so simple the equations to be estimated in an actual study will contain a number of additional terms)?

1) A wage-price spiral model can accommodate stagflation easily; when price inflation is greater than wage inflation, the real wage falls from period to period; this reduces consumption spending, and aggregate demand falls, so unemployment rises, bringing a tendency to stagnation if anything, this would weaken the ability of la- 
bour and households to pass on the cost of living. But while this might weaken wage inflation, it would not necessarily weaken the ability of firms to pass along increases in costs. Hence we have stagflation.

2) We can generate an explanation for the apparent success of the Phillips curve. Consider a case of inflation triggered by an external shock, say an increase in oil price. But in this case assume that unions are strong and firms relatively weak in their ability to pass on cost increases. So wage inflation will be greater than price inflation, and this will lead the real wage to rise, stimulating consumption, with the result that aggregate demand increases; so unemployment will fall as inflation progresses. Inflationary expectations will develop, which will also encourage demand. The faster the inflation, the stronger the demand stimulus, so inflation not only leads to a rise in employment; accelerating inflation leads to faster increases in employment. In short, we have an inverse relation between unemployment and inflation. This looks like a Phillips curve, but it is not one. Both of these "pass-along" relationships depend on there being a broadly positive relation between real wages and employment, running through the effect of real wages on consumption spending, and impacting aggregate demand through multiplier re-spending. By contrast, mainstream theory operates with a labour market based on supply and demand curves, according to which real wages are inversely related to employment and output. This, in turn results from the assumption that there is a "well-behaved" aggregate production function-which brings us to another controversy! But this time the issue is not so much facts about how the world works-at first glance empirical studies appear to support the production function. Instead we face a conceptual tangle that has to be unraveled.

\subsection{Example of Conceptual Analysis: Production Functions}

Production functions are fundamental to conventional theory; prices, for example, are supposedly set in the light of variations in marginal costs, and real wages are thought to reflect variations in marginal productivity. Marginal productivity, in turn, together with factor supplies, supposedly determines the relative shares of labour and capital, and in competitive conditions, their prices (rates of return). But when it comes to facing facts, the neoclassical story looks like a fairytale. Evidence from interviews, together with observation of business practices, suggests that prices are set by reference to the development of markets, the possible or actual actions of competitors, and to cover normal costs. But marginal costs do not generally play a role. As for real wages, physical marginal productivity is either impossible to measure (think of white-collar work, or service industries), or appears as a matter of fact to be constant over a wide range, so cannot play much of a role. Even worse, marginal products are often inferred from cost data. Mainstream economists simply assume that there are marginal products; they exist, although we may have difficulty in measuring them. But do they? What, exactly, does it mean to say that the marginal product of labor in a certain industry or service exists?

To claim this, it must be assumed that the processes of production in a modern economy (including mass production and high-tech industries) can be modeled by a continuous production function with positive first and negative second derivatives that is, showing diminishing returns ${ }^{8}$. Theory requires that different points on the function represent different technologies, the consequences of substitution. Varying intensity of use of given plant and equipment—output changing with the level of employment—does not generate points on the theoretical function, as Hicks (1932, p. 20) pointed out [42]. But this is what we get from empirical data. Moreover, studies of costs in mass production economies tend to show that costs are either constant over a large range, or that they tend to show economies of scale and fall. Evidence goes back to the Oxford Studies of the 1930s and has been confirmed over and over again (Hall and Hitch, 1933; Andrews, 1949; Gordon, 1983; Lavoie, 1992) [43]-[46]. This indicates that it would be more accurate to assume constant or increasing returns. Increasing returns are frequently found in network systems, which are widespread in high technology firms.

Nevertheless, the economics profession appears to be wedded to neo-Classical production functions with diminishing returns, generating downward sloping demand curves for labour, and rising marginal cost curves for firms. Why such support for a fairytale? One reason is that it appears to be easy to "estimate" such functions empirically, using simple regression techniques, and that the functions so estimated seem to have a good fit, and to be statistically significant. This is a good example of what is wrong with a great deal of mainstream econometrics $^{9}$. When looked at carefully, what is actually being measured seems to be quite different from what the in-

\footnotetext{
${ }^{8}$ In largely agricultural and craft economies diminishing marginal returns to productive activities may be plausible. But the technology of mass production was designed precisely to eliminate such phenomena. Further details see [15].

${ }^{9}$ For example, see Acemoglu (2009, ch. 3) [47], ch. 3, where estimation of production functions is presented uncritically. For a thoughtful discussion, see Temple (2006) [48].
} 
vestigators think they are estimating. The evidence actually matches a linear cost function, and is mistakenly used to estimate a constant returns production function. Felipe and Adams (2005, p. 430) re-examined Douglas's initial calculations, using his data set and conclude that all the aggregate Cobb-Douglas function regression captures is the path of the value added accounting identity according to which value added equals the sum of the wage bill plus total profits [49]. The Cobb-Douglas form is simply derived as an algebraic transformation of the identity.

This critique goes back to Phelps Brown (1957) [50], but was developed more fully by Simon (Simon and Levy, 1963, Simon 1979) [51] [52], and later, by Shaikh $(1974,1980)$ [53] [54]. Essentially, if shares of wages and profits are constant, the estimation will almost always "work"; that is, a Cobb-Douglas can be fitted and the elasticities will measure relative shares. Examples have been given using data sets in which there is no marginal variation, or which have been generated by completely different processes (e.g. dots spelling out the letters of the word HUMBUG), yet with constant shares, production functions can be fitted, and generally seem to have all the desirable properties. (The procedure will also work for the CES (constant elasticity of supply) and other functional forms, though perhaps not quite as well).

The basic point can be stated simply: differentiate the income identity with respect to time:

$$
Y=w N+r K
$$

where $w=w / \pi$ the real wage. Then

$$
\mathrm{d} Y / Y=[w N / Y] \mathrm{d} w / w+[r K / Y] \mathrm{d} r / r+[w N / Y] \mathrm{d} N / N+[r K / Y] \mathrm{d} K / K
$$

Let $\alpha=r K / Y$ be capital's share, so that $(1-\alpha)$ is labour's share. Then we have

$$
\mathrm{d} Y / Y-\alpha[d K / K]-(1-\alpha) \mathrm{d} N / N=\alpha(\mathrm{d} r / r)+(1-\alpha)(\mathrm{d} w / w)
$$

Two empirical assumptions, both more or less stylized facts, come into play at this stage. The first is that shares are constant, and the second is that wages grow at a steady rate while the rate of profit stays constant (features of the Victorian equilibrium). (All that is necessary is that the weighted average be constant). Then the RHS above will be a constant, call it $\lambda$, and we have

$$
\mathrm{d} Y / Y=\lambda+\alpha[\mathrm{d} K / K]+(1-\alpha) \mathrm{d} N / N
$$

which can be integrated into a Cobb-Douglas (see Temple, 2006) [48].

Note that $\lambda$, the weighted average of wage and profit growth, may be a function of time, which is usually interpreted as technical progress. We have assumed it to be constant here, but if there is a time trend, a functional form will have to be specified. If the form chosen is incorrect, this will undermine the estimation ${ }^{10}$. But a good or "correct" choice (a non-linear form or "adjustments" to the capital stock) will capture the variation in $\lambda$, and improve the fit of the "production function" (Felipe and McCombie, 2005, pp. 473-474) [55].

Interestingly, constant shares are not necessary if the estimation is being made with wage and profit data, as Laibman and Nell (1977) pointed out [56]. An estimation made from cost data could provide an apparent fit if the data were derived from fluctuations in wages and profits arising from a wage-price inflationary spiral, of the kind we have just examined. In such a spiral the data will fulfill a condition that appears to imply that the rate of profit equals the marginal product of capital. From the well-behaved neo-Classical production function we can derive an expression for the wage-profit trade-off condition:

$$
\mathrm{d} w / \mathrm{d} r=-K / N
$$

This is derived as follows. Start with:

$$
Y=Y(K, N) \Rightarrow y=y(k)
$$

From Euler's condition

$$
w=y(k)-k y^{\prime}(k) \text { and } r=y^{\prime}(k)
$$

Then

$$
\mathrm{d} w=y^{\prime} \mathrm{d} k-k y^{\prime \prime} \mathrm{d} k-y^{\prime} \mathrm{d} k=-k y^{\prime \prime} \mathrm{d} k \text {, and } \mathrm{d} r=y^{\prime \prime} \mathrm{d} k
$$

\footnotetext{
${ }^{10}$ As in the case of Solow's reply to the original Humbug paper; he used a linear time trend that would have invalidated his own original 1957 estimates (Felipe and McCombie, 2005, p. 482; Shaikh, 1980).See [55] and [54].
} 
So

$$
\mathrm{d} w / \mathrm{d} r=-k ; \text { that is, } \mathrm{d} r / \mathrm{d} w=-N / K
$$

This is a feature of a constant returns to scale production function, and is basic to marginal productivity theory, since it is necessary if paying factors their marginal products is always to add up to output.

But this relationship also characterizes the income identity, since

$$
Y=(w / \pi) N+r K
$$

which, when put in per capita form, differentiated and rearranged, gives

$$
\mathrm{d} y=k \mathrm{~d} r+r \mathrm{~d} k+\mathrm{d} w
$$

and this implies that the rate of profit equals the marginal product of capital,

$$
r=\mathrm{d} y / \mathrm{d} k \text {, if and only if } \mathrm{d} w / \mathrm{d} r=-k \text {, that is }-K / N
$$

However, going back to the accounting identity, breaking the real wage into the money wage and the price level, and differentiating, we can derive

$$
\mathrm{d} r=w N / K \pi[\mathrm{d} \pi / \pi-\mathrm{d} w / w]
$$

The change in $r$ depends on the difference between the rates of price and wage inflation, the central issue in our model of the wage-price spiral. Re-arranging and recalling the expression for the differential of a ratio,

$$
\mathrm{d} r / \mathrm{d}(w / \pi)=-N / K
$$

This can be rewritten as

$$
N \mathrm{~d}(w / \pi)=-K \mathrm{~d} r
$$

This means that value is conserved when wages decline and profit increases, or vice versa; a change in the distribution of income does not alter the amount of the income being distributed. Arguably this is an essential property of a capitalist economy; and, since it follows directly from Euler's Theorem, it is an essential property of the neo-Classical production function. Yet data generated by Keynesian inflation-a wage-price spiral—will also exhibit value conservation! That is, the data so generated will meet this same condition, and therefore will "fit" a production function, even though there may have been little or no actual variation in output, and no marginal products exist.

This misidentification has appeared over and over again, in the best places, usually without the problem even being recognized. It begins to look something like an intellectual scandal—but unfortunately, it is not the only case of misidentification due to an uncritical assumption that standard theory must be correct.

\section{Conclusions: Summing up and Moving on}

Nell's UMF is an attempt to further develop Nell's arguments so as to illuminate the importance of certain elements of the foundations of macroeconometric methodology. Nell's UMF rests on methodological institutionalism, which could be considered a kind of structuralism in that the institutions, which are defined by formal relationships, generate the observed phenomena. Institutions may be related to one another in formal and legal ways, and when assembled together, these relationships-internal relationships-may also be considered structures. Nell approaches the explanation of economic events in terms of a social world made up of institutions, roles, responsibilities, powers, etc.

Critical realism considers the socio-economic system to be made up of "structured objects" whose powers exist independently of our knowledge or perception (Lawson, 1997) [57]. The wording is a little abstract, but it is easy to understand; the policeman has the power to arrest us, and the President of the United States has the power to call up the National Guard, whether we know it or not. These objects, relationships, powers and duties constitute the basis of the causal relationships that economic science describes. Employers can hire and fire workers and can order them around; firms can move capital from place to place, opening and closing plants.

Nell's UMF, like critical realism, contends that social structures are based on obligations, contracts and promises, and the structures maintain their existence through interdependent production and reproduction.

Conceptual analysis and fieldwork will help us define the relationships, and tell us where and how to look for ways to measure them. However, estimating the parameters is not easy, as we can see from the widespread 
presence of uncertainty and volatility, and from the fact that patterns of uncertainty are more likely to change in some areas than in others. It is important not only to distinguish reliable and volatile, but to clearly specify where each is paramount.

This leads us to an important question: how should macro models be developed? In the conventional view, individual agents make choices, based on their preferences, when faced with varying economic data; and then these choices are aggregated. This approach builds from the bottom up—atoms are combined into moleculeshowever, such an aggregation is, in a sense, arbitrary, even accidental. The preferences are individual and unexplained. Surely some, or many, of the individual choices could have been quite different; surely they could change any time, at a moment's notice. We all know that as people's lives change-their preferences change. It is unjustifiable, from observation, to presume them to be constant.

In Nell's UMF it is assumed that there are contracts, obligations, and social norms, combined with the technologies in place that govern the ways households and businesses can, and normally do, act. Household spending, for example, is governed by the norms of the marriage contract, the normal obligations of parents to children, the expectations of employers and society at large (and the laws) regarding normal dress, the technology of transportation, and so on. Different categories of households will be governed by somewhat different normsworking class, middle class, professionals, and the like. And the various households within a category can be expected to follow the norms somewhat differently. If we have a good understanding of the grounds for the target, and the reasons for the deviations, we can collect information about the distribution, and set up a stochastic model of the relationship.

To conclude, econometrics is about economics; it proposes using measurement to amplify, develop and test explanations, and with it, our understanding of the structure of the economy and how it works; it is not about forecasting, or about reliable statistical relationships that lack economic content. Econometrics has the potential to-when applied to actual economic phenomenon—provide numerical content to economics, making it possible to test and amplify economic theory by directly applying it empirically.

\section{Acknowledgements}

Karim Errouaki is coauthor with Edward J. Nell of Rational Econometric Man (London, Elgar, 2013),with Edward J. Nell and Federico Mayor Zaragoza of Reinventing Globalization after the Crash (2014), and with Edward J. Nell of Hard Drugs \& Easy Money (forthcoming, 2015). He is a former Special Advisor to UN Secretary General Dr. Boutros Boutros Ghali and to Director General of UNESCO Dr. Federico Mayor Zaragoza. He is currently Senior Research Fellow at the Foundation for the Culture of Peace (Autonomous University of Madrid) and Special Advisor to Director General of CAFRAD, Pan-African Intergovernmental Organization. This paper is an updated version of a paper I presented at the Polytechnic University of Madrid, March $18^{\text {th }}$, 2013. But It is also partly based on material in Chapters 10 and 11 of a book (Rational Econometric Man, 2013), co-authored by Edward Nell and Karim Errouaki. I appreciate the response of the distinguished audience at that meeting. I would especially like to thank Professor Ramiro Cercos who arranged for the talk. I owe a great debt of gratitude to Professors Edward J. Nell, Willi Semmler, Alessandro Vercelli, Gary Mongiovi, and Tom Phillips who read and commented on several drafts of this paper and made important suggestions and many editorial improvements. At various stages in the progress of this work, I received comments and suggestions or materials from many professors. I would like to thank all of them: Lawrence Boland, Marcel Boumans, Lucas Bernard, Ramiro Cercos, George Davis, Christian Deblock, Oscar de Juan Asenjo, Eladio Febrero Paños, Jesus Ferreiro, Angelo Fusari, Davide Gualerzi, Geoffrey M. Hodgson, Lawrence Klein, Stephen Kinsella, Stéphane M. Mouandjo, Robert Mundell, Anwar Shaikh, Aris Spanos, Davide Gualerzi and Vela Velapullai. I thank three anonymous referees for highly valuable and constructive advice. The usual disclaimer applies.

\section{References}

[1] Klein, L.R. (1985) Did Mainstream Econometric Models Fail to Anticipate the Inflationary Surge? In: Feiwel, G.R., Ed., Issues in Contemporary Macroeconomics and Distribution, State University of New York Press, New York, 289296.

[2] Nell, E.J. and Errouaki, K. (2013) Rational Econometric Man, Transforming Structural Econometrics. Edward Elgar, Aldershot.

[3] Vercelli, A. (1991) Methodological Foundations of Macroeconomics: Keynes and Lucas. Cambridge University Press, 
Cambridge.

[4] Spanos, A. (2012) Revisiting Haavelmo’s Structural Econometrics: Bridging the Gap between Theory and Data. Virginia Tech Working Paper.

[5] Akerlof, G.A. and Shiller, R.J. (2009) Animal Spirits: How Human Psychology Drives the Economy, and Why It Matters for Global Capitalism. Princeton University Press, Princeton.

[6] Fair, R.C. (2012) Has Macro Progressed? Journal of Macroeconomics, 34, 2-10.

[7] Nell, E.J. and Semmler, W. (2009) Financial Crisis, Real Crisis and Policy Alternatives. Constellations, 16, $251-270$.

[8] Stiglitz, J. (2011) Rethinking Macroeconomics: What Went Wrong and How to Fix It. Global Policy, 2, 165-175.

[9] Malinvaud, E. (1988) Econometric Methodology at the Cowles Commission: Rise and Maturity. Econometric Theory, 4, 187-209.

[10] Malinvaud, E. (1998) La Modélisation en Macroéconomie Appliquée: Quarante Ans Après. Cahiers Économiques de Bruxelles, 160, 329-342.

[11] Fair, R.C. (2004) Estimating How the Macroeconomy Works. Harvard University Press, Cambridge.

[12] Haavelmo, T. (1997) Econometrics and the Welfare State. American Economic Review, 87, 13-15.

[13] Klein, L. (1987) The ET Interview: Professor L.R. Klein. Econometric Theory, 3, 409-460.

[14] Hendry, D.F. (2004) The ET Interview. Econometric Theory, 20, 743-1404.

[15] Nell, E.J. (1998) General Theory of Transformational Growth. Cambridge University Press, Cambridge. http://dx.doi.org/10.1017/CBO9780511571794

[16] Nell, E.J. (2004) Critical Realism and Transformational Growth. In: Lewis, P., Ed., Transforming Economics, Routledge, London, 76-95.

[17] Hollis, M. and Nell, E.J. (1975) Rational Economic Man: A Philosophical Critique of Neoclassical Economics. Cambridge University Press, Cambridge. http://dx.doi.org/10.1017/CBO9780511554551

[18] Haavelmo, T. (1944) The Probability Approach in Econometrics. Econometrica, 12.

[19] Haavelmo, T. (1958) The Role of the Econometrician in the Advancement of Economic Theory. Econometrica, 26, 351-357. http://dx.doi.org/10.2307/1907616

[20] Granger, C.W.J. (2004) Critical Realism and Econometrics: An Econometrician’s Viewpoint. In: Lewis, P., Ed., Transforming Economics, Routledge, London, 96-106.

[21] Johnston, J. (1984) Econometric Methods. 3rd Edition, McGraw-Hill, New York.

[22] Keynes, J.M. (1936) The General Theory of Employment, Interest and Money. Macmillan, London.

[23] Keynes, J.M. (1973) Collected Writings. Moggridged, D., Ed., Macmillan, London.

[24] Malinowski, B. (1922) Argonauts of the Western Pacific: An Account of Native Enterprise and Adventure in the Archipelagoes of Melanesian New Guinea. Routledge and Kegan Paul, London.

[25] Ho, K. (2009) Liquidated: An Ethnography of Wall Street. Duke University Press, Durham and London. http://dx.doi.org/10.1215/9780822391371

[26] Thomas, A.B. (2004) Research Skills for Management Studies. Routledge, London.

[27] Mintzberg, H. (1973) The Nature of Managerial Work. Harper Collins College, New York.

[28] Blinder, A.S. (1998) Asking About Prices: A New Approach to Understanding Price Stickiness. Russell Sage Foundation.

[29] Bewley, T. (1999) Why Wages Don’t Fall during a Recession. Harvard University Press, Cambridge.

[30] Lucas, R.E. (1987) Models of Business Cycles. Basil Blackwell, Oxford.

[31] Rosenberg, A. (1992) Economics: Mathematical Politics or Science of Diminishing Returns. University of Chicago Press, Chicago.

[32] Allais, M. (1997) An Outline of My Main Contributions to Economic Science. American Economic Review, 87, 3-12.

[33] Marshall, A. and Marshall, M.P. (1879) The Economics of Industry. Macmillan, London.

[34] Hendry, D.F. (1995) Dynamic Econometrics. Oxford University Press, Oxford. http://dx.doi.org/10.1093/0198283164.001.0001

[35] Wulwick, N.J. (2001) The Phillips Curve: Which? Where? To Do What? How? www.scribd.com/doc/8420056/Nobelio-Laureatai

[36] Moore, B.J. (1988) Horizontalists and Verticalists: The Macroeconomics of Credit and Money. Cambridge University Press, Cambridge. 
[37] Nell, E.J. and Forstater, M., Eds. (2003) Functional Finance. Edward Elgar, Cheltenham.

[38] Nell, E.J. and Bell, S.A., Eds. (2003) The State, the Market and the Euro. Edward Elgar, Cheltenham.

[39] Wray, L.R. (2003) The Neo-Chartalist Approach to Money. In: Nell, E.J. and Bell, S.A., Eds., The State, the Market and the Euro, Edward Elgar, Cheltenham, 9-110.

[40] Robinson, J. (1980) What Are the Questions? And Other Essays: Further Contributions to Economics. M.E. Sharpe, New York.

[41] Flaschel, P., Franke, F. and Proano, C. (2008) On the Determinacy of New Keynesian Models with Staggered Wage and Price Setting. IMK Working Paper 11-2008, IMK at the Hans Boeckler Foundation, Macroeconomic Policy Institute.

[42] Hicks, J.R. (1932) The Theory of Wages. Macmillan, London.

[43] Hall, R. and Hitch, C. (1939) Price Theory and Business Behaviour. Oxford Economic Papers, 2, 12-45.

[44] Andrews, P.W.S. (1949) Manufacturing Business. Macmillan, London.

[45] Gordon, R.A. (1983) A Century of Evidence on Wage and Price Stickiness in the United States, the United Kingdom, and Japan. In: Tobin, J., Ed., Macroeconomics, Prices and Quantities, Basil Blackwell, Oxford.

[46] Lavoie, M. (1992) Foundations of Post-Keynesian Economic Analysis. Edward Elgar, Aldershot.

[47] Acemoglu, D. (2009) Introduction to Modern Economic Growth. Princeton University Press, Princeton.

[48] Temple, J. (2006) Aggregate Production Functions and Growth Economics. International Review of Applied Economics, 20, 301-317. http://dx.doi.org/10.1080/02692170600736052

[49] Felipe, J. and Adams, F.G. (2005) A Theory of Production: The Estimation of the Cobb-Douglas Function: A Retrospective View. Eastern Economic Journal, 31, 427-445.

[50] Brown, P. (1957) The Meaning of Fitted Cobb-Douglas Functions. Quarterly Journal of Economics, 71, 546-560. http://dx.doi.org/10.2307/1885710

[51] Simon, H. (1979) Rational Decision-Making in Business Organizations. American Economic Review, 69, $493-513$.

[52] Simon, H. and Levy, F. (1963) A Note on the Cobb-Douglas Function. Review of Economic Studies, 30, 93-104. http://dx.doi.org/10.2307/2295806

[53] Shaikh, A. (1974) Laws of Production and Laws of Algebra: Humbug Production Function: A Comment. Review of Economics and Statistics, 56, 115-120. http://dx.doi.org/10.2307/1927538

[54] Shaikh, A. (1980) Laws of Production and Laws of Algebra: Humbug II. In: Nell, E.J., Ed., Growth, Profits and Prosperity, Cambridge University Press, Cambridge, 80-95. http://dx.doi.org/10.1017/CBO9780511571787.007

[55] Felipe, J. and McCombie, J.S.L. (2005) How Sound Are the Foundations of the Aggregate Production Function. Eastern Economic Journal, 31, 467-488.

[56] Laibman, D. and Nell, E.J. (1977) Reswitching, Wicksell Effects, and the Neoclassical Production Function. American Economic Review, 63, 100-113.

[57] Lawson, T. (1997) Economics and Reality. Routledge, London and New York. http://dx.doi.org/10.4324/9780203195390 
Scientific Research Publishing (SCIRP) is one of the largest Open Access journal publishers. It is currently publishing more than 200 open access, online, peer-reviewed journals covering a wide range of academic disciplines. SCIRP serves the worldwide academic communities and contributes to the progress and application of science with its publication.

Other selected journals from SCIRP are listed as below. Submit your manuscript to us via either submit@scirp.org or Online Submission Portal.
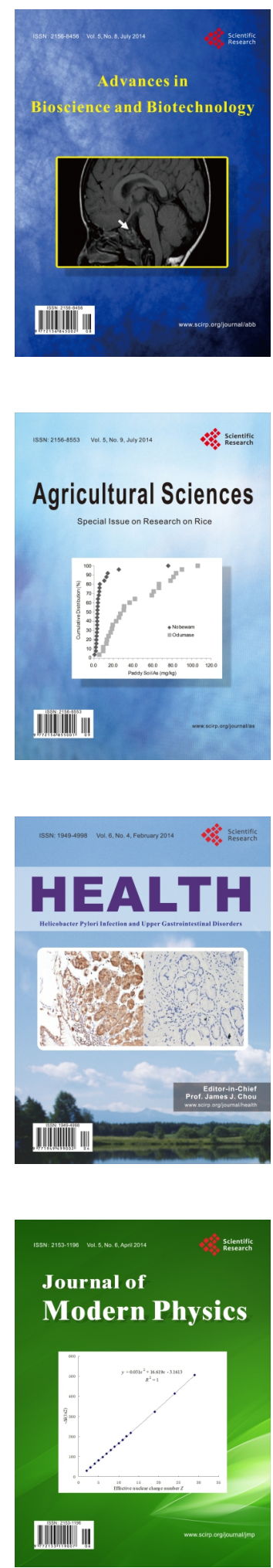
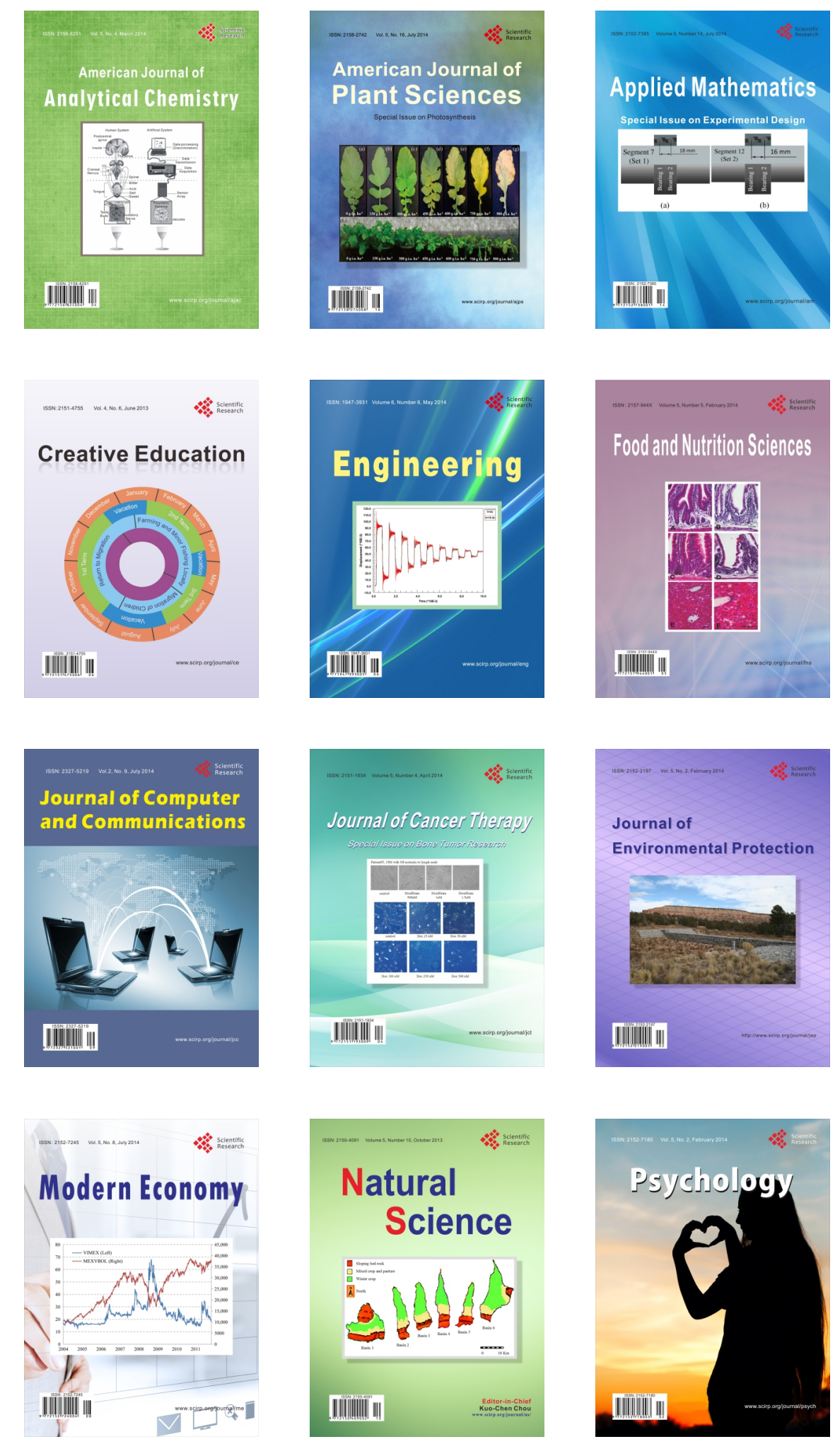